\title{
Estimating greenhouse gas emissions using emission factors from the Sugarcane Development Company, Ahvaz, Iran
}

\author{
Amir Zahedi ${ }^{1}$, Sorour Ghodrati ${ }^{2}$, Mehdi Ahmadimoghaddam $^{3}$, Nematollah Jaafarzadeh ${ }^{4}$ \\ ${ }^{1}$ Committee Research, Department of Environmental Health Engineering, School of Health, Ahvaz Jundishapur University of Medical \\ Sciences, Ahvaz, Iran \\ ${ }^{2}$ Department of Environmental Assessment and Land Use Planning, School of Environment and Energy, Islamic Azad University, \\ Science and Research Branch, Tehran, Iran \\ ${ }^{3}$ Environmental Technologies Research Center, Department of Environmental Health Engineering, School of Health, Ahvaz Jundishapur \\ University of Medical Sciences, Ahvaz, Iran \\ ${ }^{4}$ Environmental Technologies Research Center, Department of Environmental Health Engineering, School of Health, Ahvaz Jundishapur \\ University of Medical Sciences, Ahvaz, Iran
}

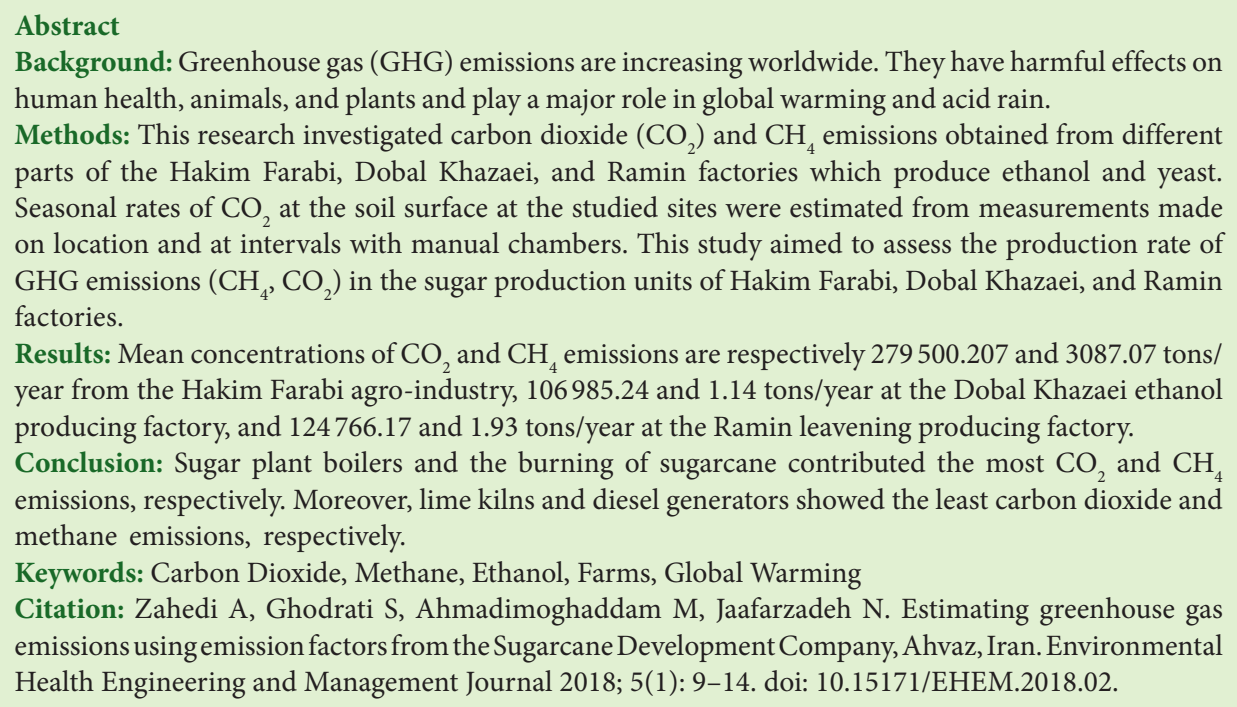

Article History:

Received: 23 April 2017

Accepted: 21 August 2017

ePublished: 3 January 2018

\section{Introduction}

Greenhouse gases (GHGs) cause a significant amount of pollution in the atmosphere (1). They are harmful to human health, animals, and plants, and they play a major role in global warming and acid rain (2). During recent decades, public concern has arisen regarding the presence of air pollutants both outdoors and indoors, and their potential to damage human health has increased $(3,4)$. Carbon dioxide $\left(\mathrm{CO}_{2}\right)$ and $\mathrm{CH}_{4}$ are the main $\mathrm{GHGs}$ today; $\mathrm{CO}_{2}$ emissions from fossil fuels are the main cause of global warming $(5,6)$. Other studies showing the importance of $\mathrm{CO}_{2}$ and $\mathrm{CH}_{4}$ rates in global warming have been conducted in some industrial and agricultural countries (7-11). The great development of the sugarcane and ethanol production industries, including agricultural industries and other technologies, seen in recent decades has created a need for recalculating the emission of pollutants and energy balances. Methane and $\mathrm{CO}_{2}$ are the main emissions of the agricultural/industrial levels (12). In the last 10 years, atmospheric concentrations of $\mathrm{CO}_{2}$ have increased by almost $40 \%$, from a preindustrial concentration of approximately 280 ppmv (parts per million volume) to almost $384 \mathrm{ppmv}$ in 2007 (13). Large reductions in GHG emissions are expected to prohibit serious climate destabilization, however, GHG emissions from fixed and transport sources are growing more quickly than other energy-using sectors and are predicted to increase GHG emissions by $80 \%$ between 2007 and 2030 (14). $\mathrm{CH}_{4}$ is produced during the production and transport of coal, natural gas, oil, and other natural resources such as fertilizer and landfills with open-path technology and other anaerobic waste treatment systems $(15,16)$. Municipal landfills are great resources of $\mathrm{CH}_{4}$ emissions; in municipal solid waste landfills, $\mathrm{CH}_{4}$ is about 
30 times more potent as a heat-trapping gas (17). About $3.6 \%$ to $7.9 \%$ of natural gas released to the atmosphere is $\mathrm{CH}_{4}$ gas (18). The main GHGs included SOx, NOx, PM, $\mathrm{CO}_{2}$, and $\mathrm{HCs}$, all of which cause global warming and increase atmospheric temperatures. Today, the proportion of $\mathrm{CO}_{2}$ and $\mathrm{CH}_{4}$ directly emitted by each country has been much discussed, have focused on $\mathrm{CO}_{2}$ emissions, as the most important GHG. Specifically, emphasis has been placed on $\mathrm{CO}_{2}$ emissions as the exhaust of fossil fuel combustion, cement and the other industrial manufactories, which is termed $\mathrm{CO}_{2}$ here, referring to fossil carbon. Increasingly, $\mathrm{CO}_{2}$ and $\mathrm{CO}$ emissions from land-use change and forestry (LUCF) are garnering much attention. However, it is not just $\mathrm{CO}_{2}$ that is causing global warming; a suite of human activities resulting in the emission of GHGs is termed climate-altering pollutants (CAPs). Among GHGs, $\mathrm{CO}_{2}$ emissions cause about onehalf of total global warming (7). The resulting contrary health outcomes cause governments to work collectively with resolution to reduce and remove GHG emissions. What has been less widely understood, though, is that policies to decrease GHG emissions (climate change mitigation policies) could pave the way for great effects on the health of people in a society $(8,19)$. GHGs in industry are emitted from two main sections. These emissions including direct and indirect emissions that are produced at the facility and occur off-site, respectively (20). After 10 years of an annual average growth rate of $4 \%$, the years 2012 and 2013 showed a decrease to about 1\%, also global $\mathrm{CO}_{2}$ emissions abated $0.5 \%$ in 2014 to the record level in 2013. In 2014, the Environmental Protection Agency (EPA) reported that industry emissions accounted for approximately $21 \%$ of the total GHG emissions in the world (21). Carbon is the most abundant element in the production of sugarcane that can be changed to $\mathrm{CO}_{2}$ and $\mathrm{CH}_{4}$ pollution as the result of burning. Some fossil fuels are used in industry and agriculture; some bagasse, for example, is used as fuel in other parts, and a portion of the bagasse is used inside the factory as fuel for the boilers used in sugar production. The current study evaluated the emission factors of GHG emissions of $\left(\mathrm{CO}_{2}\right)$ and $\left(\mathrm{CH}_{4}\right)$ in the production of Hakim Farabi agriculture and industry, which includes raw sugar and sugarcane, and Dobal Khazaei and Ramin factories that produce alcohol and yeast. Industries, factories, and farms emit large quantities of $\mathrm{CO}_{2}$ and $\mathrm{CH}_{4}$ during the various stages of production. The main sources of $\mathrm{CO}_{2}$ and $\mathrm{CH}_{4}$ emissions are fuel-consuming equipment, such as boilers, lime kilns, diesel generators, electrical equipment in factories, and sugarcane burning for the elimination of waste; thus, $\mathrm{CO}_{2}$ is emitted during the process of producing alcohol.

\section{Methods}

Description of the study area

This study was performed in Ahvaz city located in southwest Iran, which includes an estimated area of
$220 \mathrm{~km}^{2}$ and an estimated density of 4815.73 people per square kilometer. The climate in Ahvaz is tropical with a limited downfall period and an extended dry period lasting generally 9 months per year (22). One of the biggest industries in this city is the Hakim Farabi agro-industry, which is in southeastern Ahvaz, located on the Kilometer 35 Road of Ahvaz-Abadan. With the geographical coordinates of zone 39R, $267920.09 \mathrm{~m} \mathrm{E}$ and 3426751.75 $\mathrm{m} \mathrm{N}$, this area has 12 thousand hectares of arable land. In addition, this complex has several units, including a sugar production unit with the capacity to produce 100000 tons of sugar per year, the alcohol production units of Dobal Khazaei, and an agricultural part including 10000 ha of arundinaceous farms. Figure 1 shows the location of the studied stations.

\section{Energy input and GHG emissions}

For this research, $\mathrm{CO}_{2}$ and $\mathrm{CH}_{4}$ emissions were obtained from different parts of the Hakim Farabi, Dobal Khazaei, and Ramin factories that produce ethanol and yeast. Sampling time and the number of samples were one year and 144, respectively. Seasonal rates of $\mathrm{CO}_{2}$ at the soil surface at the sites were estimated from measurements made on location and at intervals with manual chambers. The soil $\mathrm{CO}_{2}$ rate was measured continuously with six automatic chambers. The rate of $\mathrm{CH}_{4}$ in the above yield was measured continuously using a micrometeorological gradient method. In addition, the emission and conversion factors were used for the $\mathrm{CO}_{2}$ and $\mathrm{CH}_{4}$ stack and emitted gasses from different sections such as boilers; field burners were vented to ambient air. One method for estimating $\mathrm{CO}_{2}$ and $\mathrm{CH}_{4}$ emissions is the ratio of energy output and input to $\mathrm{GHG}$ emissions, which demonstrates the quantity of $\mathrm{CO}_{2}$ and $\mathrm{CH}_{4}$ by measuring the concentrations of these gases in the fuel.

\section{Results}

The results of this study showed that $\mathrm{CO}_{2}$ and $\mathrm{CH}_{4}$ emissions from the Hakim Farabi agro-industry are 279500.207 and 3087.07 tons/year, respectively, from the Dobal Khazaei ethanol producing factory are 106985.24 and 1.14 tons/year, respectively, and from the leavening producing factory is 124766.17 and 1.93 tons/ year, respectively. Sugarcane is cultivated in an area of

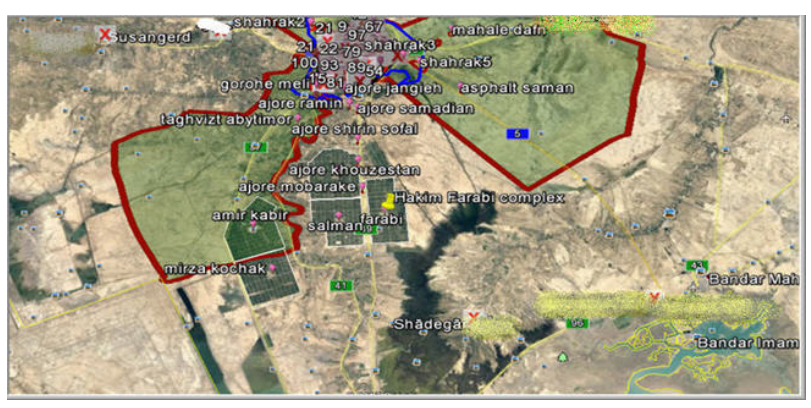

Figure 1. Locations of the studied stations. 
Table 1. $\mathrm{CO}_{2}$ and $\mathrm{CH}_{4}$ emission factors in sugarcane factories

\begin{tabular}{|c|c|c|c|c|}
\hline Emission resource & Gas & Emission factor & Unit & Reference \\
\hline \multirow{2}{*}{ Sugarcane straw Burning in the field } & $\mathrm{CO}_{2}$ & 1.66 & $\mathrm{~g} / \mathrm{kg}$ & CEPA (23) \\
\hline & $\mathrm{CH}_{4}$ & 2.7 & $\mathrm{~g} / \mathrm{kg}$ & CEPA \\
\hline \multirow{2}{*}{ Trash burning in the field } & $\mathrm{CO}_{2}$ & $1.3-1.4$ & $\mathrm{~kg} /$ tones & EPA (24) \\
\hline & $\mathrm{CH}_{4}$ & 2.7 & $\mathrm{~kg} /$ tones & IPCC (24) \\
\hline \multirow{2}{*}{ Boiler emission } & $\mathrm{CO}_{2}$ & 1891 & $\mathrm{~g} / \mathrm{m}^{3}$ fuel & CAPP (25) \\
\hline & $\mathrm{CH}_{4}$ & 0.03 & $\mathrm{~g} / \mathrm{m}^{3}$ fuel & CAPP \\
\hline \multirow[t]{2}{*}{ Limestone burning emission } & $\mathrm{CO}_{2}$ & 3.14 & $\mathrm{~kg} / \mathrm{m}^{3}$ fuel & $\begin{array}{l}\text { Canada can met energy diversification } \\
\text { research laboratory ( } 26)\end{array}$ \\
\hline & $\mathrm{CH}_{4}$ & 0.12 & Ton $\mathrm{CO}_{2} / 1000 \mathrm{~m}^{3}$ fuel & CAPP \\
\hline \multirow{2}{*}{ Diesel generator } & $\mathrm{CO}_{2}$ & 2.68 & $\mathrm{Kg} \mathrm{CO}_{2} / \mathrm{L}$ fuel & SEIA (27) \\
\hline & $\mathrm{CH}_{4}$ & 0.13 & g CH4/L fuel & Canada national inventory report \\
\hline
\end{tabular}

12000 hectares in the Farabi farm. The main sources of GHG emissions in this complex are open burning in the field, boilers, limestone burning, diesel generators, and electrical equipment. Emission rates for the different parts were calculated using the following formula. Table 1 indicates the emission factor for $\mathrm{CO}_{2}$ and $\mathrm{CH}_{4}$ gases in sugarcane factories as different guidelines. Emission factor and emission rate are common and simple indices used to show GHG emissions. Table 2 indicates the $\mathrm{CO}_{2}$ and $\mathrm{CH}_{4}$ emission rates at different units of the Dobal Khazaei factory.

Emission rate $=$ emission factor $*$ fuel type (22)

The emission factors in different parts of the factory based on type of fuel are as follows:

Emission factor $=$ Emission rate $/$ Fuel type

Figure 2 shows the carbon dioxide and methane emission rates during harvest; this emission factor obtained from bagasse burning that occurred as open-field burning at the Hakim Farabi farm.

Dobal Khazaei factory is one of the main factories in the region. It produces the largest amounts of ethanol and leaven in the country. In this factory, there are 3 sources of $\mathrm{CO}_{2}$ emissions (boilers, the ethanol unit, and electrical equipment) and two sources of $\mathrm{CH}_{4}$ emissions (boilers and electrical equipment). Figure 3 shows a comparison of $\mathrm{CO}_{2}$ and $\mathrm{CH} 4$ emission rates from different emission sources at the Hakim Farabi factory. Figure 4 shows the $\mathrm{CO} 2$ and $\mathrm{CH} 4$ emission rates at the Dobal Khazaei factory.

Methane and carbon dioxide emissions

Methane and carbon dioxide are emitted from different parts of the Hakim Farabi and Dobal Khazaei complexes, including the burning of sugarcane fields before harvest,

Table 2. $\mathrm{CO}_{2}$ and $\mathrm{CH}_{4}$ emission rates from Dobal Khazaei factory

\begin{tabular}{llc}
\hline Emission resource & Gas & Emission (ton/year) \\
\hline Boiler (ethanol production ) & $\mathrm{CO}_{2}$ & 10892.16 \\
Leaven production process & $\mathrm{CH}_{4}$ & 0.20 \\
\multirow{2}{*}{ Boilers (Leaven production process) } & $\mathrm{CO}_{2}$ & 14000 \\
& $\mathrm{CO}_{2}$ & 7412.72 \\
& $\mathrm{CH}_{4}$ & 0.14 \\
\hline
\end{tabular}

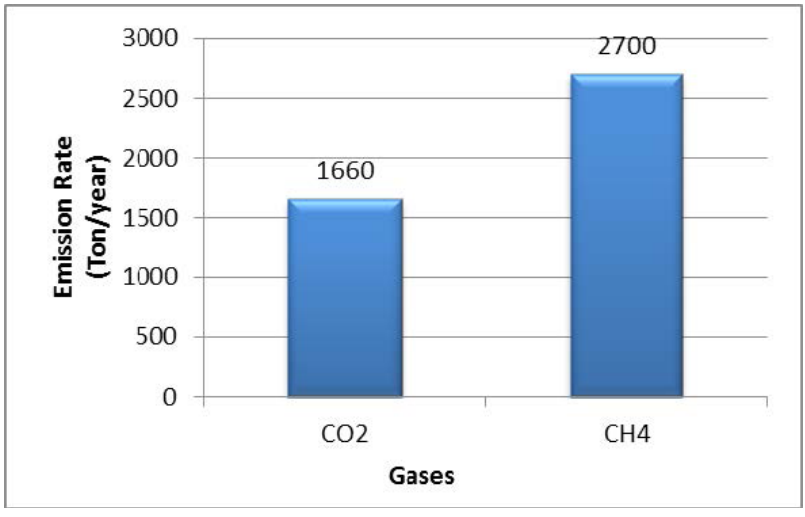

Figure 2. Open-field burning at Hakim Farabi farm.
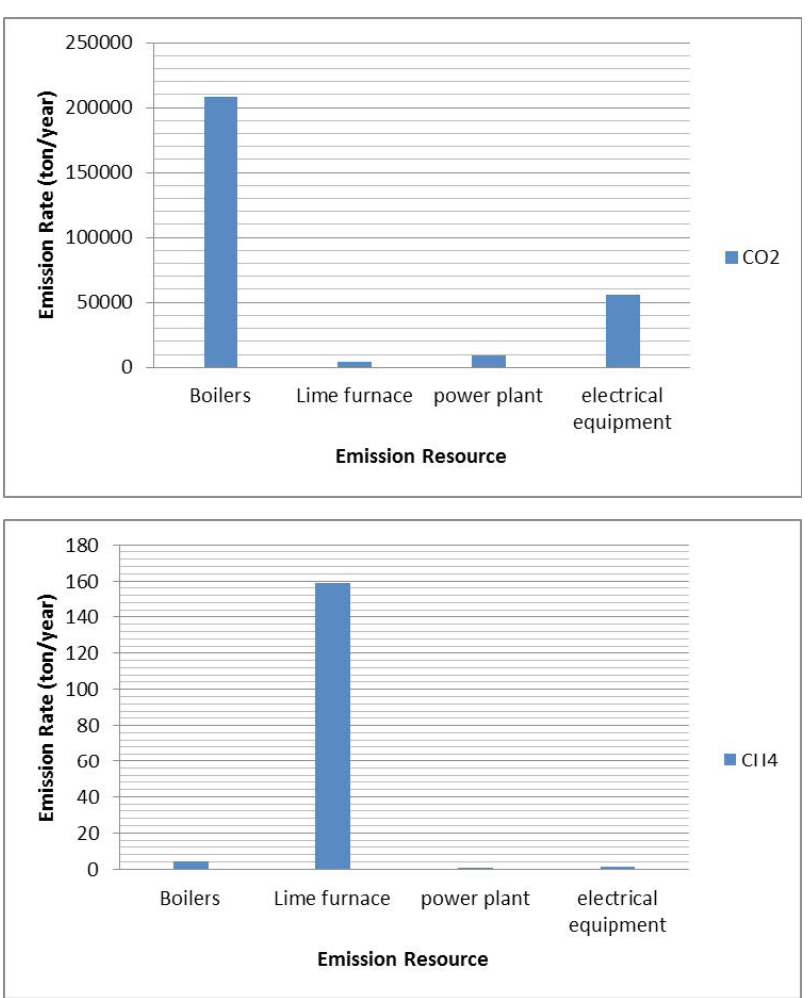

Figure 3. Comparison of $\mathrm{CO}_{2}$ and $\mathrm{CH}_{4}$ emissions from different sources at Hakim Farabi Sugar factory 
using stillage as fertilizer, boilers, and burning ethanol in ethanol engines. Results of this study indicate the emission factor for $\mathrm{CH}_{4}$ and $\mathrm{CO}_{2}$ in Hakim Farabi farm. During the burning of sugarcane trash in the field, $\mathrm{CH}_{4}$ is the main gas produced and emitted; $\mathrm{CO}_{2}$ emissions are insignificant. Therefore, the bulk of $\mathrm{CH}_{4}$ emissions are produced in field by trash burning, whereas $\mathrm{CO}_{2}$ emissions resulting from open burning in the field are related to bagasse and cane waste. Figure 5 shows the comparison of $\mathrm{CO}_{2}$ and $\mathrm{CH}_{4}$ emissions from different sources. A recent study that analyzed emission factors for sugarcane and simulated burning in a wind tunnel indicated that GHG emissions were $0.32 \mathrm{~kg} / \mathrm{t}$ (dry fuel) in the case of a spreading fire and $0.59 \mathrm{~kg} / \mathrm{t}$ (dry fuel) for fire in a pile. In transient or disturbed boiler processes, $\mathrm{CH}_{4}$ emissions are produced only from unburnt organics.

\section{Discussion}

In this study, GHG emissions from five main factory sources were investigated, including the sugarcane farm, boilers, limestone burning, diesel generators, and electrical equipment. The Farabi cane crop was transferred from the farm to the Farabi, Dobal Khazaei, and Ramin factories to become the final products such as ethanol and sugarcane. Therefore, sugarcane mills produce sugar, ethanol, Leaven, which are splatted and sent to respond to market needs. Straw and sugarcane that are cut and burned on the Hakim Farabi farm produce the greatest amounts of $\mathrm{CO}_{2}$ and $\mathrm{CH}_{4}$ emissions. In addition, bagasse, the residue of
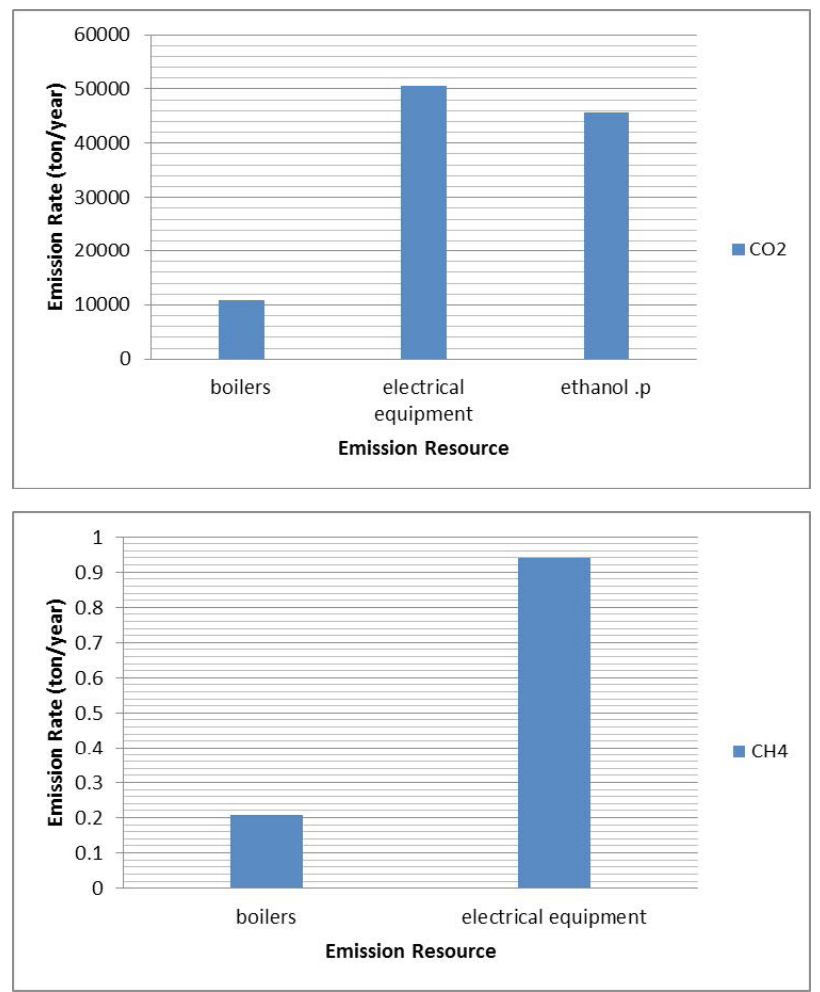

Figure 4. Comparison of $\mathrm{CO}_{2}$ and $\mathrm{CH}_{4}$ emissions from different sources at Dobal Khazaei factory sugarcane sap dewatered from sugarcane, is combusted in sugar factories to produce steam and electricity. Nguyen and Gheewala showed in their study that the methane emission rate from sugarcane burning is $3.5 \mathrm{~kg} /$ ton. They also revealed that open burning on the farm caused a $\mathrm{CH}_{4}$ emission rate of $2.2 \mathrm{~kg} / \mathrm{ton}$. Their results were obtained by the emission factor (28). The Hakim Farabi and Dobal Khazaei factories are major producers of sugar, leaven, and ethanol, and their activities produce a large quantity of $\mathrm{CO}_{2}$ and $\mathrm{CH}_{4}$ emissions. Ordinarily, GHG emissions are produced in winter, which is the harvest season. The GHGs emissions from these factories along with particulate matter (PM) are considered synergistic agents. The California Environmental Protection Agency revealed that the $\mathrm{CO}_{2}$ and $\mathrm{CH}_{4}$ emission rates from the open burning of sugarcane for the production of ethanol are 315.973 and $514.1 \mathrm{~g} / \mathrm{ton}$, respectively (29), but in the current study, $\mathrm{CO} 2$ and $\mathrm{CH} 4$ emission rates of 1660 and $2700 \mathrm{~g} /$ ton were determined (Figure 2 ). Boilers are another part of the factories that release high concentrations of $\mathrm{CO}_{2}$ and $\mathrm{CH}_{4}$ emissions into the atmosphere. Boilers, lime furnaces, diesel generators, and electrical equipment are internal units in the Hakim Farabi Complex And are used in the production of sugar and ethanol. The GHG emissions in these processes are caused by the internal burner. This unit of the factory uses natural gas and gasoline; therefore, the emission and energy rates related to gasoline are affected by the class of the crude oil, the petroleum refinery configuration, and
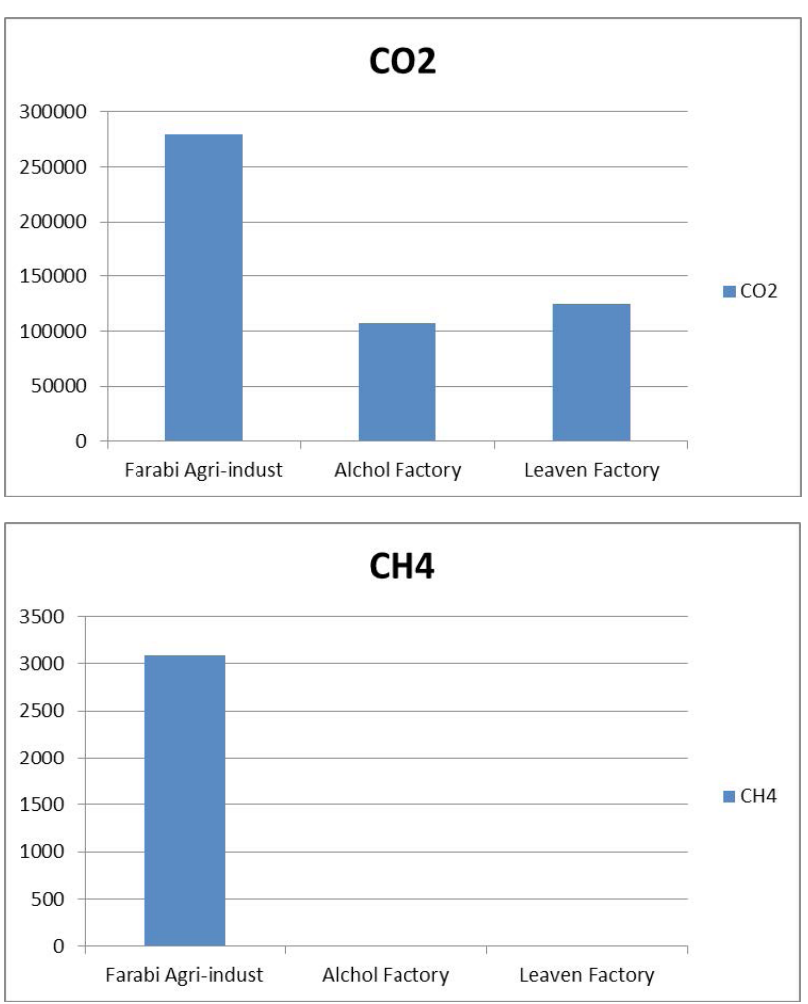

Figure 5. Comparison of $\mathrm{CO}_{2}$ and $\mathrm{CH}_{4}$ emissions from different sources in the whole complex 
such factors as natural gas, petrol, and gasoline quality (11). The lime furnace uses natural gas, and therefore produces a high amount of $\mathrm{CH}_{4}$. The power plant unit is one of the main parts of the Hakim Farabi complex. It uses six diesel generators to supply electricity to the entire Hakim Farabi complex. In this unit, the use of gasoline fuel could not be determined as local reliable documents were not available. Thus, international consolidated data about energy consumption and GHG emissions in the production of oil-derived fuels was used in this study. The electrical equipment is another main unit in the Hakim Farabi factory. This unit supplies electrical energy for the entire Hakim Farabi complex.

Total bagasse production is almost 1129222 tons/year (2014) at 50\% moisture. It is the sum of bagasse which percentage of bagasse will be lost in different ways, and this is used as fuel in some industries such as paper pulp and food industries. However, the main part of bagasse is used in sugar mills as an energy resource to produce sugar or ethanol. Also some of bagasse are used to produce sugar and ethanol. The bagasse to sugar ratio is 1:1, and the bagasse to ethanol ratio is $0.5: 1$.

Sugarcane farming correlates with a significant amount of GHG emissions such as $\mathrm{CO}_{2}$ and $\mathrm{CH}_{4}$, from both upstream processes such as fertilizer production and from the field itself. The nitrogen in bagasse (i.e. straw) on the farm is also the $\mathrm{N}$ in fertilizer and emits $\mathrm{N}_{2} \mathrm{O}$. Open field burning was done in farm, by physical harvesting of sugarcane, and transportation logistics. These two activities are the main GHG emission sources in the sugarcane ethanol life cycle. In the last decade, mechanical harvesting increased the speed of operations. This technology also increased fuel consumption by $20 \%$; however, the use of bigger equipment and new technology is replacing these methods. Automatic harvesting will increase to $50 \%$ in the next 8 years (10). However, mechanical harvesting will increase GHG emissions in the atmosphere. Moreover, an increase in green cane reaping will produce a huge volume of trash. This could increase GHG emissions due to open burning in the field. Most boilers do not have wet scrubbers, and $\mathrm{CH}_{4}$ emissions have not been reported. The most significant pollutants emitted by bagasse boilers are $\mathrm{CO}_{2}$ and $\mathrm{PM}$, which can travel long distances in the atmosphere and be transferred to Ahvaz city atmosphere. Due to the higher volume of gases emitted from this agroindustry complex, it is suggested that this factory should use scrubbers and filters to control gases and use biofilters to remove gases through the use of microorganisms.

\section{Conclusion}

The Hakim Farabi, Dobal Khazaei, and Ramin are the most important sugar and ethanol factories in Iran, and they release a great amount of GHG emissions into the atmosphere. In these factories, GHG emissions come from five main sources: the sugarcane farm boilers, limestone burning, diesel generators, and electrical equipment. In these factories, straw and bagasse are burned in the field, and open burning released significant concentrations of $\mathrm{CO}_{2}$ and $\mathrm{CH}_{4}$ into the atmosphere. Ordinarily, GHG emissions are produced in winter, which is the harvest season. The GHG emissions from these factories along with PMs are considered synergistic agents. The emission rates for the different parts of the factories were calculated. The results showed that in the Hakim Farabi factory, boiler emissions, electrical equipment, diesel generator, limestone burning emissions, sugarcane straw burning in the field, and trash burning in the field released the highest concentrations of $\mathrm{CO}_{2}$, respectively. Furthermore, sugarcane straw burning and trash burning in the field produced the biggest percentage of methane emissions. In open burning, the $\mathrm{CH}_{4}$ emissions are greater than the $\mathrm{CO}_{2}$ emissions. In the Dobal Khazaei factory, electrical equipment, ethanol, and boilers released the highest concentrations of $\mathrm{CO}_{2}$ into the atmosphere. Also, the electrical equipment produced the highest rate of $\mathrm{CH}_{4}$ emissions into the atmosphere.

\section{Acknowledgments}

This research project was financially supported by the Environmental Technologies Research Center, Ahvaz Jundishapur University of Medical Sciences (grant No. ETRC 9012).

\section{Ethical issues}

It is confirmed that this manuscript is the original work of the authors. It has not been published, nor is it under review in another journal, and it is not being submitted for publication elsewhere.

\section{Competing interests}

The authors declare that they have no competing interests.

\section{Authors' contribution}

All authors contributed equally and participated in the collection, analysis, and interpretation of the data. All authors critically reviewed, refined, and approved the manuscript.

\section{References}

1. Samaras C, Meisterling K. Life cycle assessment of greenhouse gas emissions from plug-in hybrid vehicles: implications for policy. Environ Sci Technol 2008; 42(9): 3170-6. doi: 10.1021/es702178s.

2. Weisser D. A guide to life-cycle greenhouse gas (GHG) emissions from electric supply technologies. Energy 2007; 32(9): 1543-59. doi: 10.1016/j.energy.2007.01.008.

3. Bastianoni S, Pulselli FM, Tiezzi E. The problem of assigning responsibility for greenhouse gas emissions. Ecol Econ 2004; 49(3): 253-7. doi: 10.1016/j.ecolecon.2004.01.018.

4. Jaafarzadeh N, Amiri H, Ahmadi M. Factorial experimental design application in modification of volcanic ash as a natural adsorbent with Fenton process for arsenic removal. Environ Technol 2012; 33(2): 159-65. doi: 
10.1080/09593330.2011.554887.

5. Davis SJ, Caldeira K. Consumption-based accounting of CO2 emissions. Proc Natl Acad Sci U S A 2010; 107(12): 5687-92. doi: 10.1073/pnas.0906974107.

6. Stocker TF, Qin D, Plattner GK, Tignor M, Allen SK, Boschung J, et al. Climate change 2013: The physical science basis. Intergovernmental Panel on Climate Change, Working Group I Contribution to the IPCC Fifth Assessment Report (AR5). New York: Cambridge Univ Press; 2013.

7. Smith KR, Desai MA, Rogers JV, Houghton RA. Joint CO2 and $\mathrm{CH} 4$ accountability for global warming. Proceedings of the National Academy of Sciences 2013; 110(31): E2865-74. doi: 10.1073/pnas.1308004110.

8. Taylor M, Tam C, Gielen D. Energy efficiency and CO2 emissions from the global cement industry. Korea 2006; 50(2-2): 61-7.

9. de Carvalho Macedo I. Greenhouse gas emissions and energy balances in bio-ethanol production and utilization in Brazil (1996). Biomass and Bioenergy 1998; 14(1): 77-81. doi: 10.1016/S0961-9534(97)00038-X.

10. Denmead OT, Macdonald B, Bryant G, Naylor T, Wilson $S$, Griffith DWT, et al. Emissions of methane and nitrous oxide from Australian sugarcane soils. Agric For Meteorol 2010; 150(6): 748-56. doi: 10.1016/j.agrformet.2009.06.018.

11. Macedo IC, Seabra JE, Silva JE. Green house gases emissions in the production and use of ethanol from sugarcane in Brazil: The 2005/2006 averages and a prediction for 2020 . Biomass Bioenergy 2008; 32(7): 582-95. doi: 10.1016/j. biombioe.2007.12.006.

12. Rafiei M, Gadgil AS, Ghole VS, Gore SD, Jaafarzadeh N, Mirkazemi R. Assessment of air pollution and its effects on the health status of the workers in beam rolling mills factory (Iran National Steel Industrial Group) from AhvazIran. Indian J Occup Environ Med 2009; 13(1): 20-2. doi: 10.4103/0019-5278.50719.

13. Doney SC, Fabry VJ, Feely RA, Kleypas JA. Ocean acidification: the other CO2 problem. Ann Rev Mar Sci 2009; 1: 169-92. doi: 10.1146/annurev.marine.010908.163834.

14. Woodcock J, Edwards P, Tonne C, Armstrong BG, Ashiru $\mathrm{O}$, Banister D, et al. Public health benefits of strategies to reduce greenhouse-gas emissions: urban land transport. Lancet 2009; 374(9705): 1930-43. doi: 10.1016/s01406736(09)61714-1.

15. Burba G, Anderson T, Ediger K, von Fischer J, Gioli B, Ham J, et al , eds. Latest on Mobile Methane Measurements with Fast Open-Path Technology: Experiences, Opportunities \& Perspectives. Vienna: EGU General Assembly; 2016.

16. Ge S, Liu L, Xue Q, Yuan Z. Effects of exogenous aerobic bacteria on methane production and biodegradation of municipal solid waste in bioreactors. Waste Manag 2016; 55: 93-8. doi: 10.1016/j.wasman.2015.11.024.

17. Jorgenson AK. Global Warming and the Neglected
Greenhouse Gas: A Cross-National Study of the Social Causes of Methane Emissions Intensity, 1995. Social Forces 2006; 84(3): 1779-98. doi: 10.1353/sof.2006.0050.

18. Howarth RW, Santoro R, Ingraffea A. Methane and the greenhouse-gas footprint of natural gas from shale formations. Clim Change 2011; 106(4): 679-90. doi: 10.1007/s10584-011-0061-5.

19. Searchinger T, Heimlich R, Houghton RA, Dong F, Elobeid A, Fabiosa J, et al. Use of U.S. Croplands for Biofuels Increases Greenhouse Gases Through Emissions from Land-Use Change. Science 2008; 319(5867): 1238-40. doi: $10.1126 /$ science. 1151861.

20. Satterthwaite D. Cities' contribution to global warming: notes on the allocation of greenhouse gas emissions. Environ Urban 2008;20(2):539-49. doi: 10.1177/0956247808096127.

21. Newell RG, Raimi D. Implications of Shale Gas Development for Climate Change. Environ Sci Technol 2014; 48(15): 8360-8. doi: 10.1021/es4046154.

22. Shahsavani A, Naddafi K, Jafarzade Haghighifard N, Mesdaghinia A, Yunesian M, Nabizadeh $\mathrm{R}$, et al. The evaluation of PM10, PM2.5, and PM1 concentrations during the Middle Eastern Dust (MED) events in Ahvaz, Iran, from April through September 2010. J Arid Environ 2012; 77: 72-83. doi: 10.1016/j.jaridenv.2011.09.007.

23. Crilly D, Zhelev T. Emissions targeting and planning: An application of $\mathrm{CO} 2$ emissions pinch analysis (CEPA) to the Irish electricity generation sector. Energy 2008; 33(10): 1498-507. doi: 10.1016/j.energy.2008.05.015.

24. Venkatram A. A critique of empirical emission factor models: a case study of the AP-42 model for estimating PM10 emissions from paved roads. Atmos Environ 2000; 34(1): 1-11. doi: 10.1016/S1352-2310(99)00330-1.

25. Chambers A, Strosher M, Wootton T, Moncrieff J, McCready P. DIAL measurements of fugitive emissions from natural gas plants and the comparison with emission factor estimates. 15th Annual Emission Inventory Conference, US Environmental Protection Agency New Orleans; 2006.

26. Ordorica-Garcia G, Croiset E, Douglas P, Elkamel A, Gupta M. Modeling the Energy Demands and Greenhouse Gas Emissions of the Canadian Oil Sands Industry. Energy Fuels 2007; 21(4): 2098-111. doi: 10.1021/ef0700984.

27. Murray SN, Walsh BP, Kelliher D, O'Sullivan DTJ. Multivariable optimization of thermal energy efficiency retrofitting of buildings using static modelling and genetic algorithms - A case study. Build Environ 2014; 75: 98-107. doi: 10.1016/j.buildenv.2014.01.011.

28. Nguyen TLT, Gheewala SH. Life cycle assessment of fuel ethanol from cane molasses in Thailand. Int J Life Cycle Assess 2008; 13(4): 301. doi: 10.1007/s11367-008-0011-2.

29. Detailed C. GREET pathway for California reformulated gasoline blendstock for oxygenate blending (CARBOB) from average crude refined in California, Version 2.1. Sacramento, CA: California Air Resources Board; 2009. 